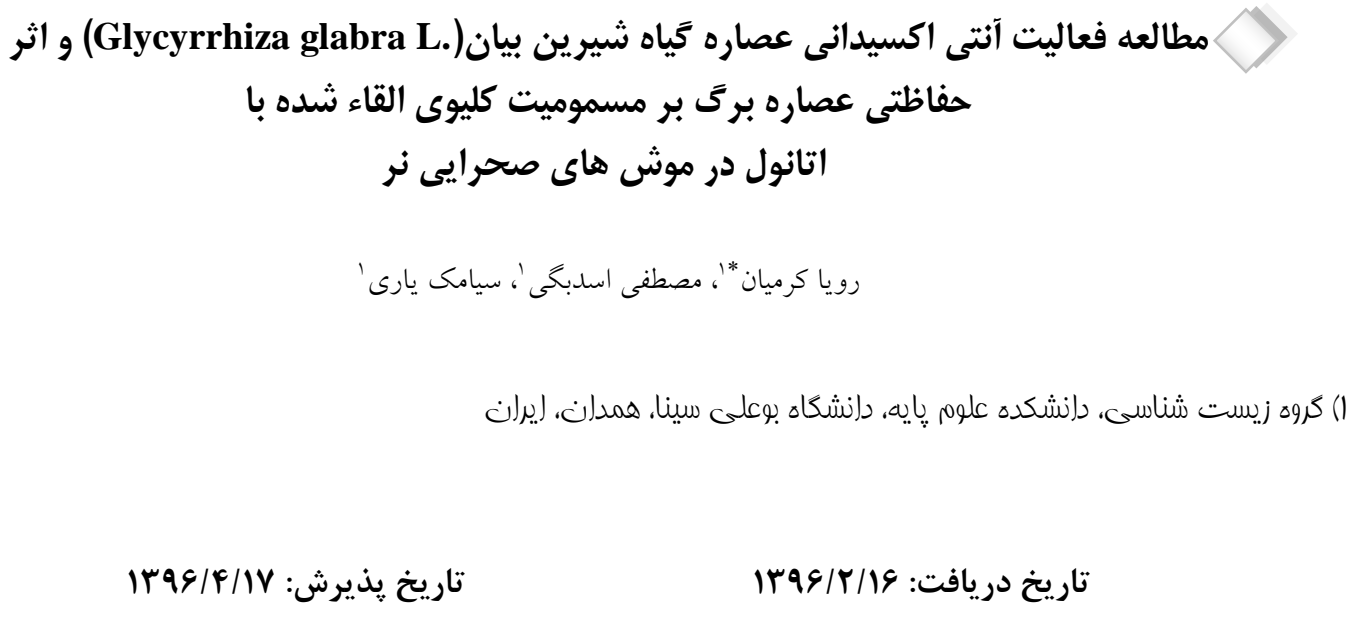

تاريخ دريافت:

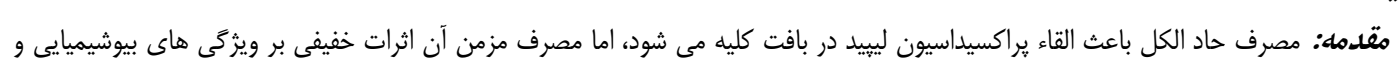

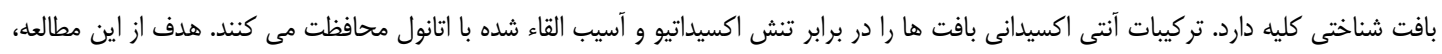

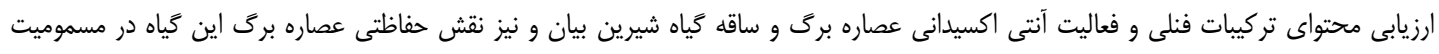
كليوى القاء شده با اتانول بود.

مواد و روثس ها: ارزيابى محتواى فنل و فلاونوئيد تام عصاره برى و ساقه شيرين بيان به ترتيب به روش هائ هاى فولين-سيوكالتو و كلريد

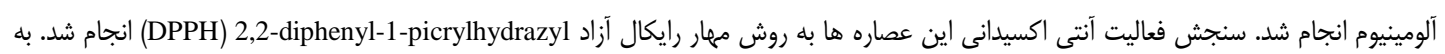

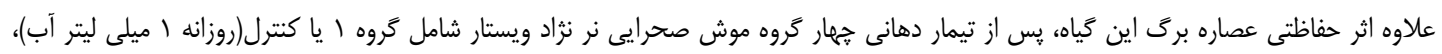

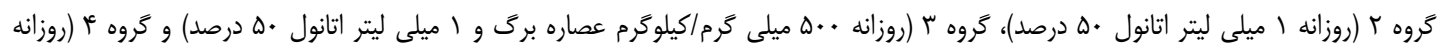

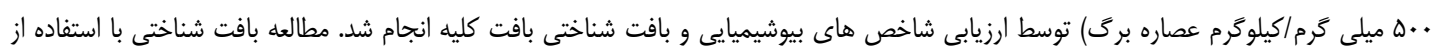

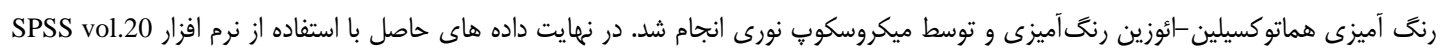

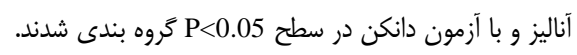

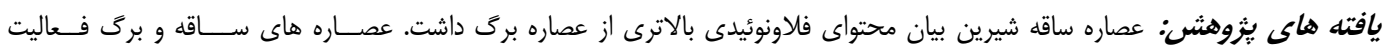

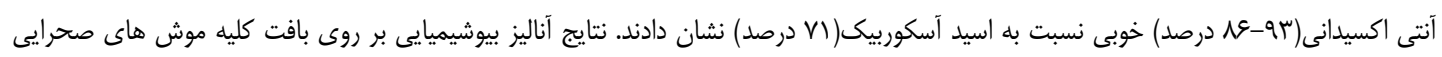

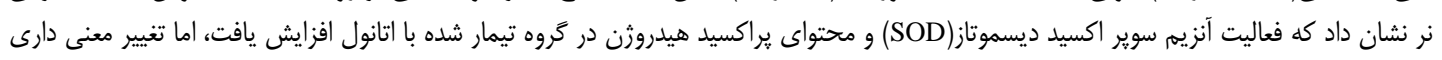

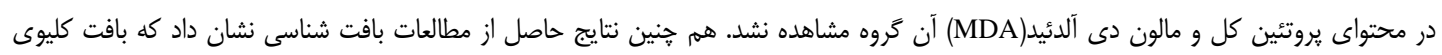

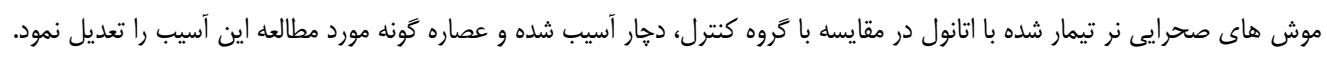

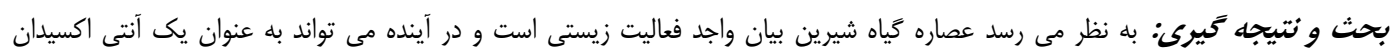

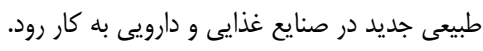

وازه هاى كليدى: شيرين بيان، فعاليت آنتى اكسيدانى، اتانول، سميت كليوى، فنل، موش صحرايى

Email: R_karamian@bau.ac.ir

* نويسنده مسئول: كروه زيست شناسى، دانشكده علوم بايه، دانشخاه بوعلى سينا، همدان، ايران

Copyright (C) 2018 Journal of Ilam University of Medical Science. This is an open-access article distributed under the terms of the Creative Commons Attribution international 4.0 International License (https://creativecommons.org/licenses/by-nc/4.0/) which permits copy and redistribute the material, in any medium or format, provided the original work is properly cited. 


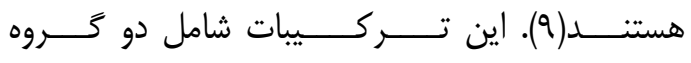
آنتى اكسيدان هاى آنزيمى و غير آنزيمى هستند.

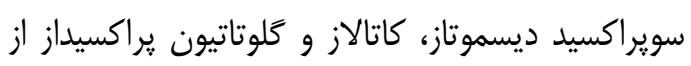
جمله مهم ترين آنزيم هاى آنتى اكسيدانى هستند كه كهاز

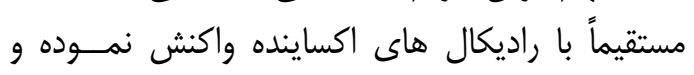

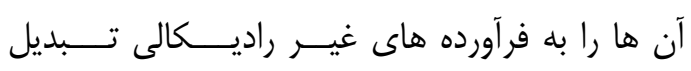

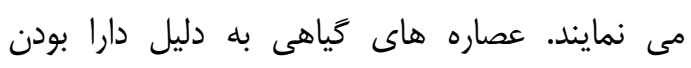

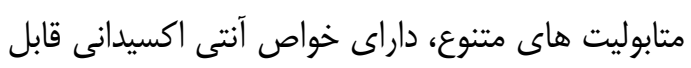

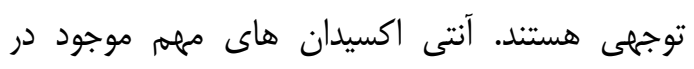

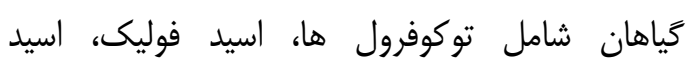
آسكوربيك، رنخَيزه هاى كاروتنوئيدى، فنيل آكريليك فيكاني

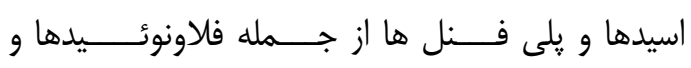

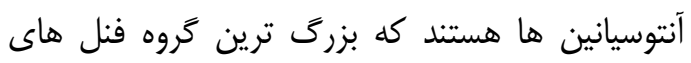

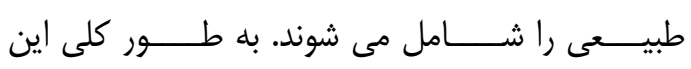

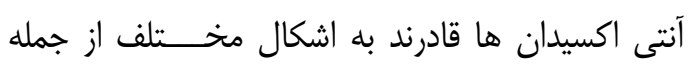

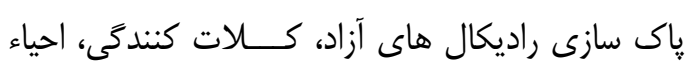

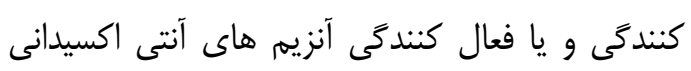

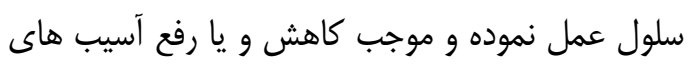

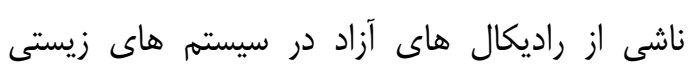
كردند(·) (1). جنس شيرين بيان(Glycyrrhiza L.

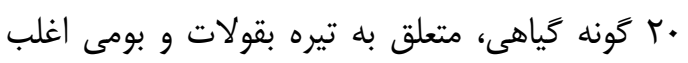

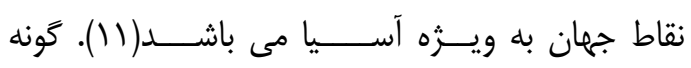
G. glabra يراكنش وسيعى در سراسر دنيا دارد. تركيبات جدا شده آنه

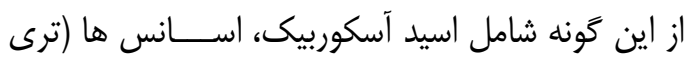

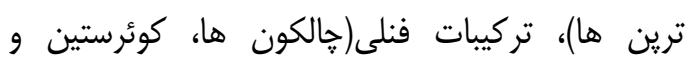

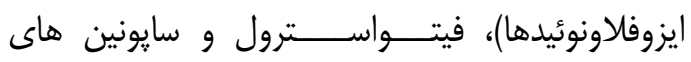

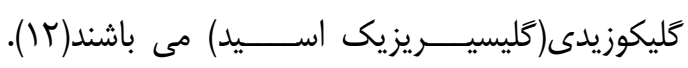

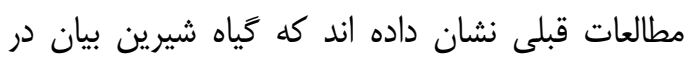

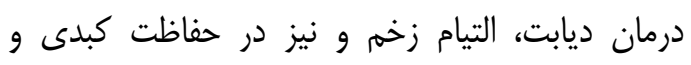

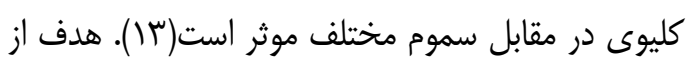
اين مطالعه ارزيابى محتواى تركيبات فنلى و فعالئ داليت

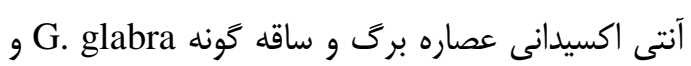
نيز بررسى اثر حفاظتى عصاره برى اين خياه بر سميت إنى كليوى القاء شده با اتانول در موش هاطى عاره صحرايى نر مى باشد.
مقدمه

راديكال هاى آزاد مشابه اكسيثن فعال به طور طبيعى در مسيرهاى متابوليسمى مختلف در سلول ها ها

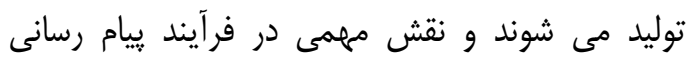

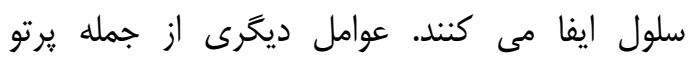

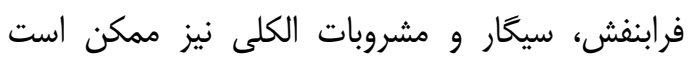

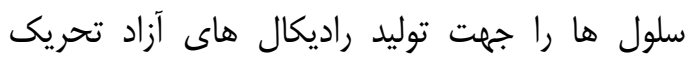

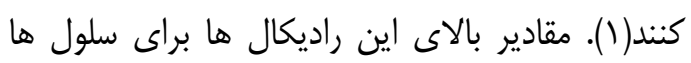

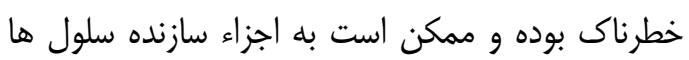

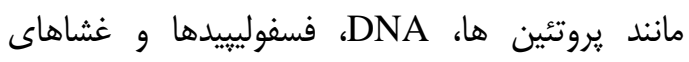

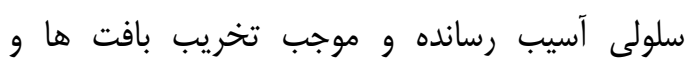
بيمارى هاى مختلف مانند التهاب، سرطان و.... كَردد( (؟). بر اساس گزارش سازمان بهداشت جهانى، حدود

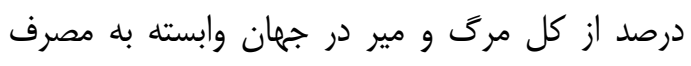
الكل است(r). مصرف حاد و مزمن الكل باعث ايجاد

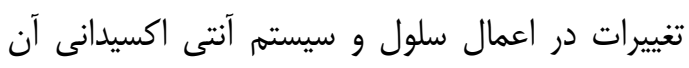

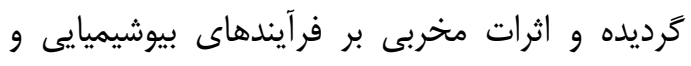

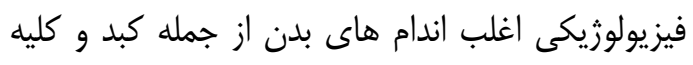

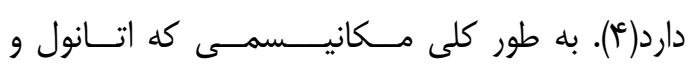
متابوليت هاى حاصل از آن موجب آسيب به بافي كافت كبان كاند

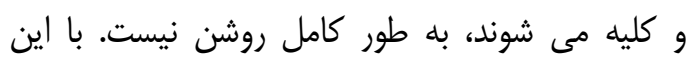
حال، برخى مطالعات نشان داده اند كه اتانول با القاء

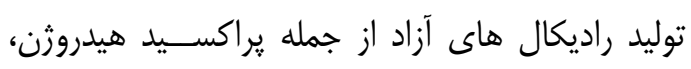
مى تواند سبب آسيب هاى سلولى و بافتى گرددد(ه، ب).

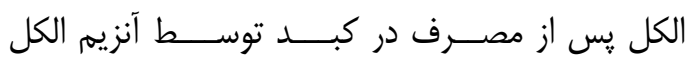
دهيدروزناز به استالدئيد تبديل شده و در در نهايت با توليد توليد راديكال آزاد سويراكسيد به استات تبديل مي شئ شود(ع).

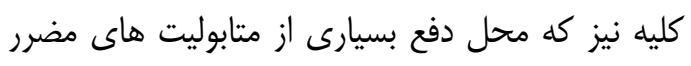

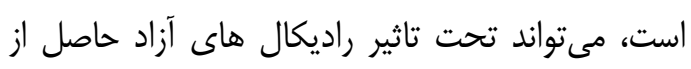

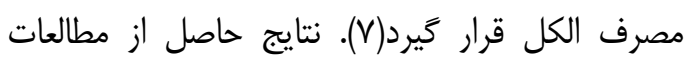
قبلى نشان داده است كه مصرف حاد الكل باعث القاء

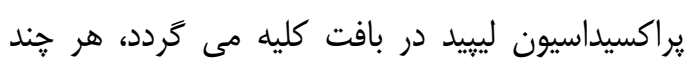
مصرف مزمن آن اثرات خفيفى بر ويثى دئى هاى

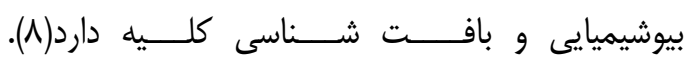
آنتى اكسيدان ها تركيبات مهمى هستند كه مى توانند سلول را در برابر اكسيداسيون محافظت نموده و و در

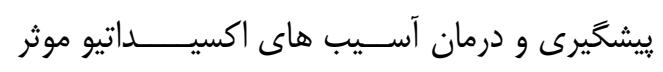


جذب آن در طول موج هأ أنانومتر قرائت شد. محتواى فلاونوئيد تام به كمك منحنى استاندارد كوئرستين

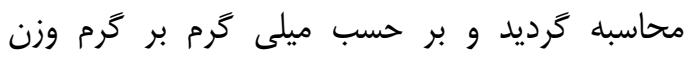

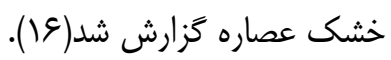

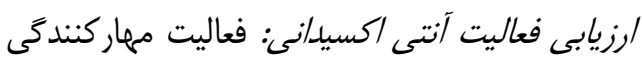

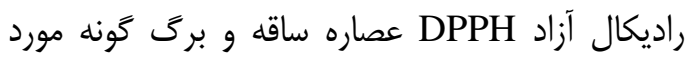

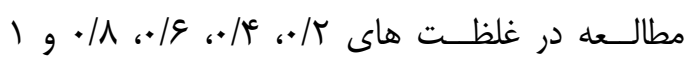

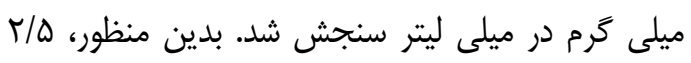

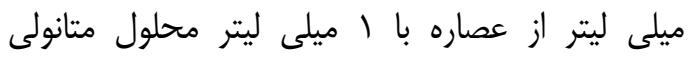

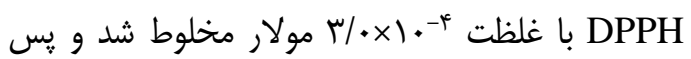

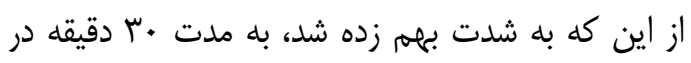

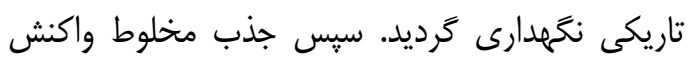

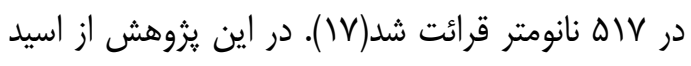

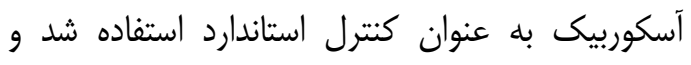

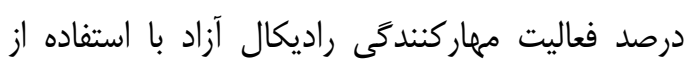
فرمول زير به دست آمد: كز

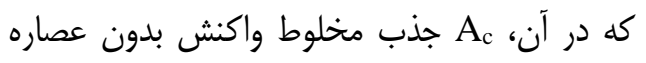

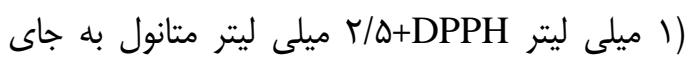

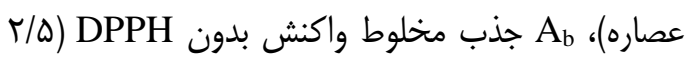
ميلى ليتر عصاره در غلظت هاى مختلف + 1 ميلى ليتر

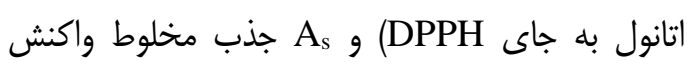

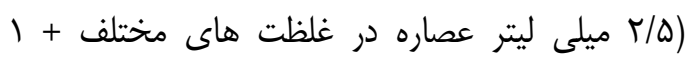
ميلى ليتر DPPH) مى باشد.

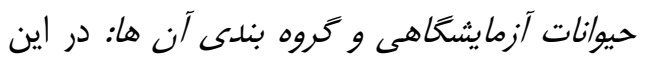
يزوهش، حيوانات(موش صحرايى نر نزاد ويستار با وزن إنا

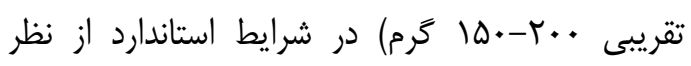

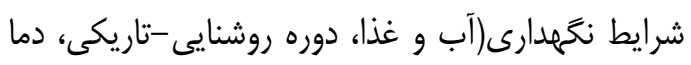

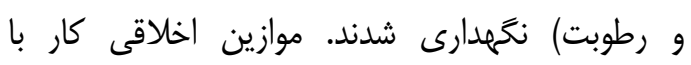

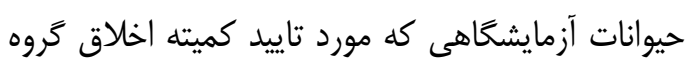

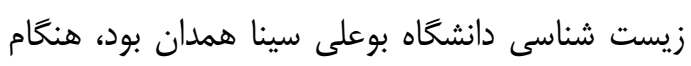

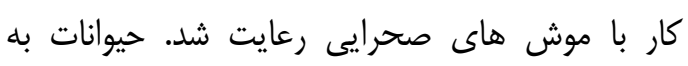

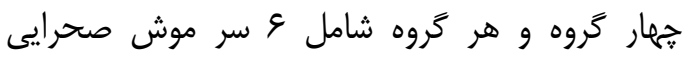

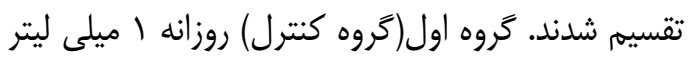

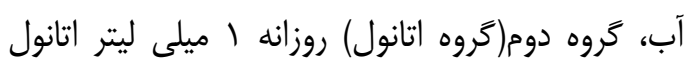

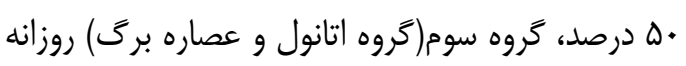

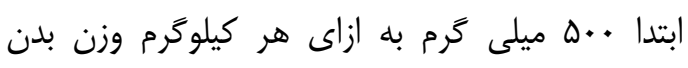

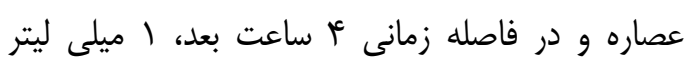

\section{مواد و روش ها}

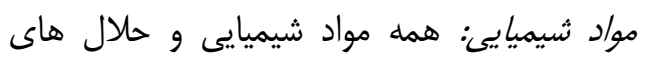

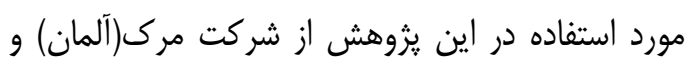

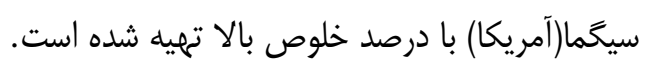

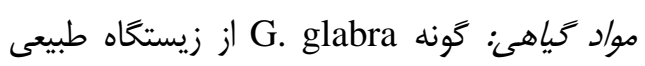
خود در استان قزوين جمع آورى شد و نمونه و شر در

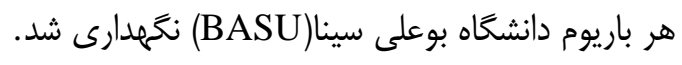

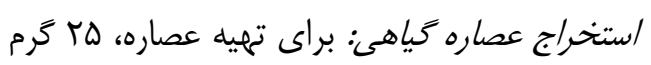

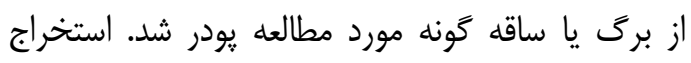

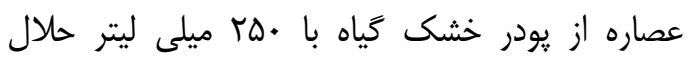

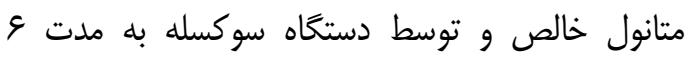

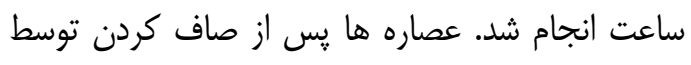

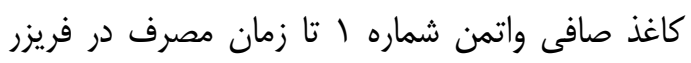

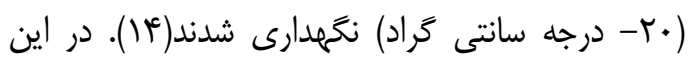

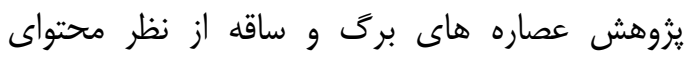
تركيبات فنلى و فعاليت آنتى اكسيدانى مورد ارزيابى

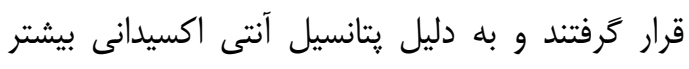

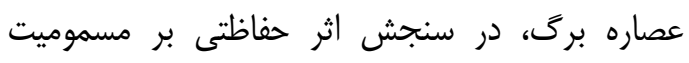

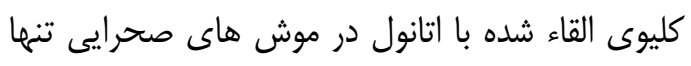
از عصاره برى استفاده شد.

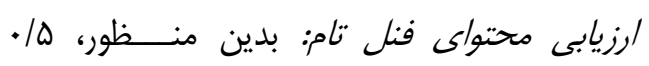

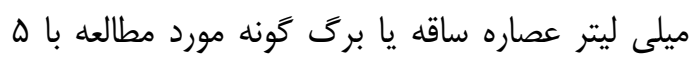

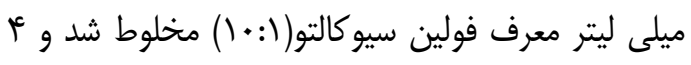

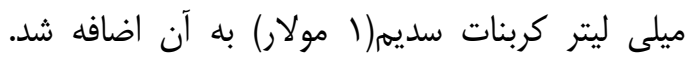

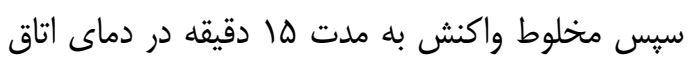

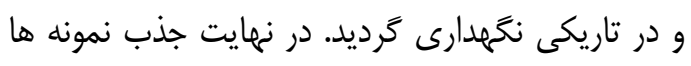
در طول موج • • نانومتر توسط دستخاه اسيكتروفتومتر Lambda مدل Perkin Elmer UV/Visible آمريكا) قرائت شد. محتواى فنل تام به كمك منحنى

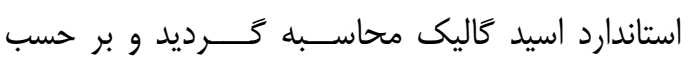

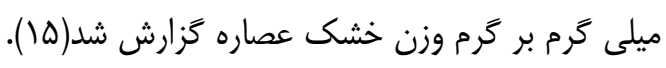

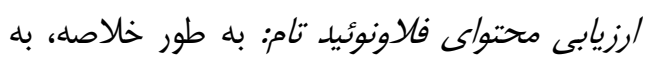

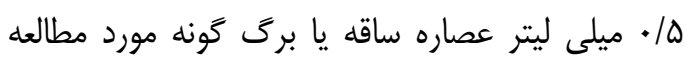

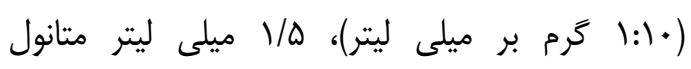

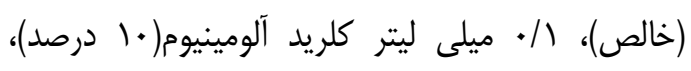

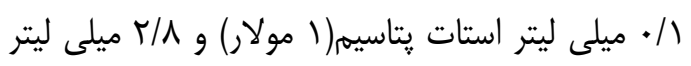

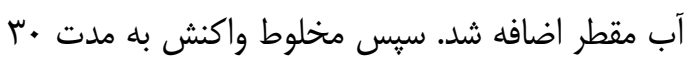

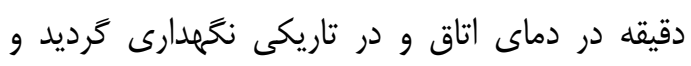


كه در آن كتترلA، جذب مخلوط واكنش بدون

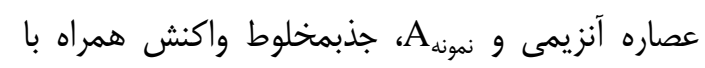
عصاره آنزيمى مىباشد.

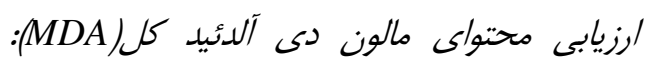

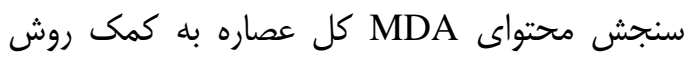
Baryla

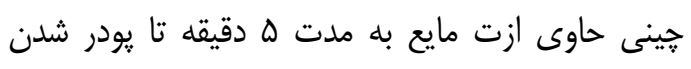

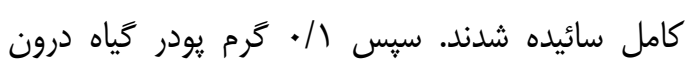

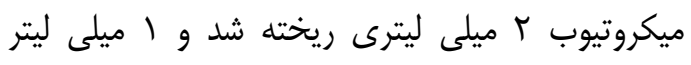

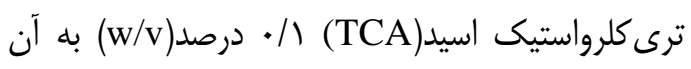

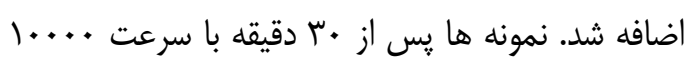

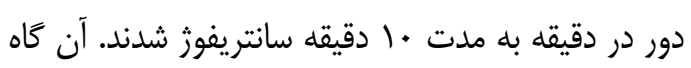

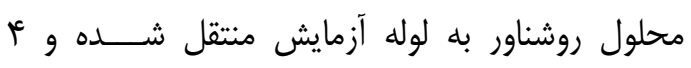

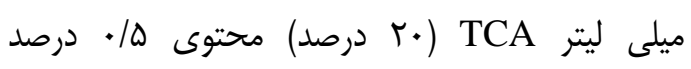

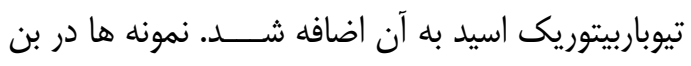
مارى در دماى ه9 درجه سانتى گراد به مدت هار ها دقيقه

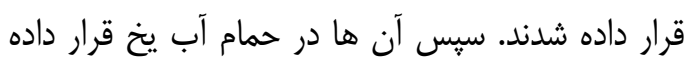

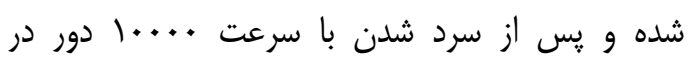

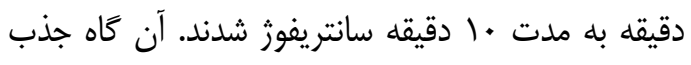

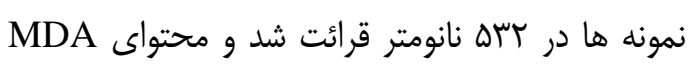

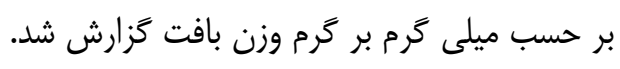
ارزيابى محتواى يراكسيد هيدروزن: براى سنجش برم

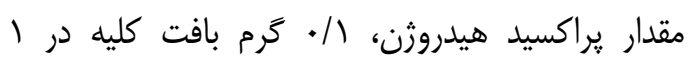

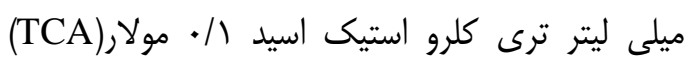

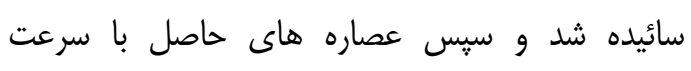

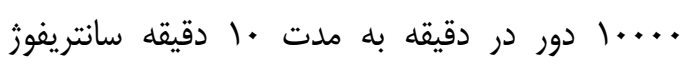

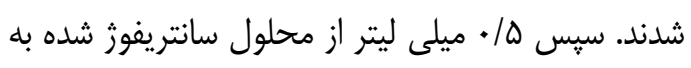

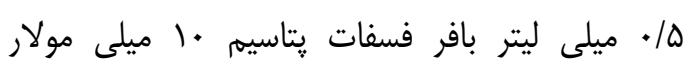
و ه / (pH: V) Fرديد و جذب مخلوط واكنش در طول موج . .

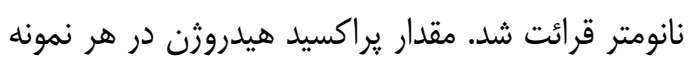

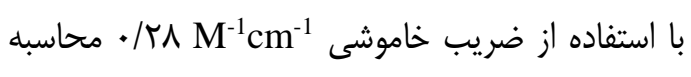

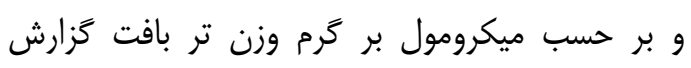

شد) غ (T).

غلظت=ضريب خاموشى/تغييرات جذب نمونه مطالعات بافت شناسى: جهت مطالعه بافي بافت شناسى، بافت كليه جدا شده و با استفاده از سرم فيزيولوزيكى مطافي

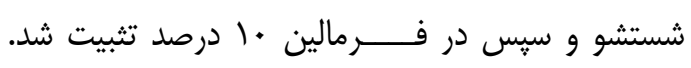

اتانول •ه درصد و گروه جهارم(گروه عصاره برگى)

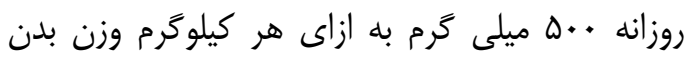

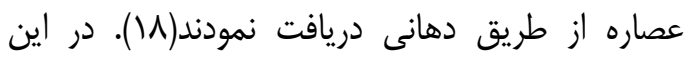
يزوهش به دليل فعاليت آنتى اكسيدانى بالاتر عصاره

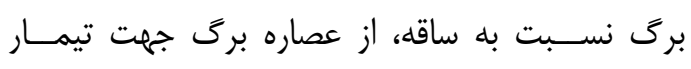

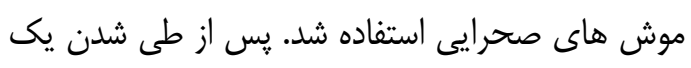

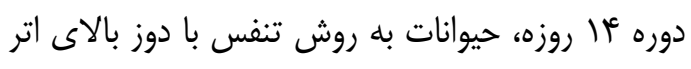
كشته شدند(1). كليه ها بلافاصله از بلدن حيوان خارج شدند و پِ از شستشو، بخشى از كليه جهت آناليز

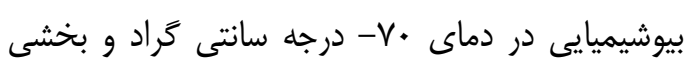

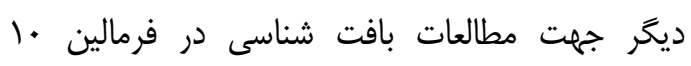
درصد نتخهدارى شد. آناليز بيوشيميا ييى و بافت شناسى بافت كليه

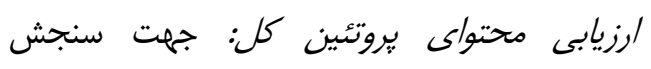
يروتئين كل، •V ميكروليتر از عصاره بافتى استخراج

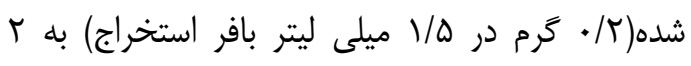

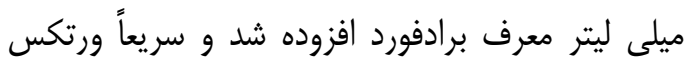

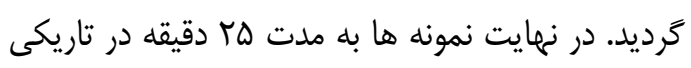

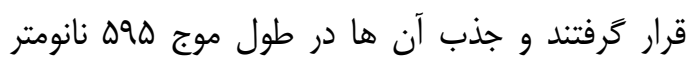
قرائت شد. در اين سنجش بالانك شامل • V ميكروليتر

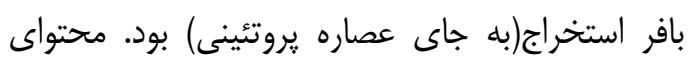

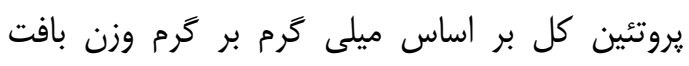

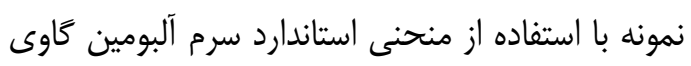
(BSA) ارزيابى فعاليت آنزيم سويراكسيد ديسموتاز (BSA) (SOD):

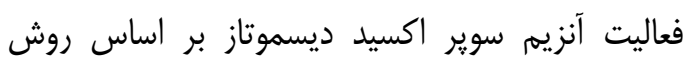

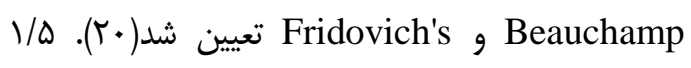

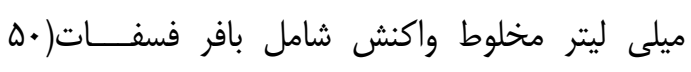

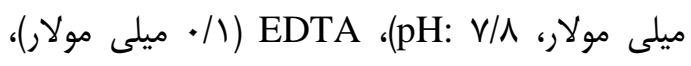

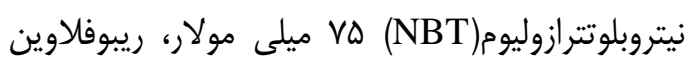

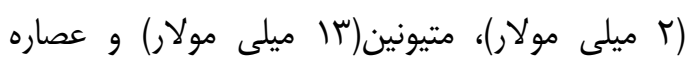

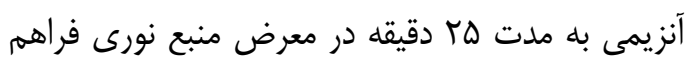

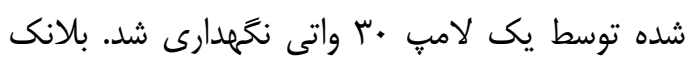

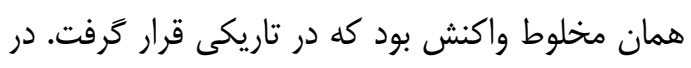
نهايت جذب نمونه ها در طول موج • •هو نانومتر خوانده

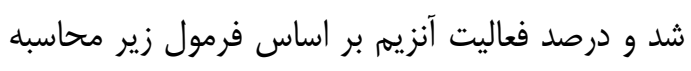

$$
\text { كترل A }
$$




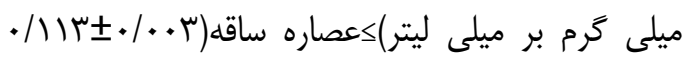

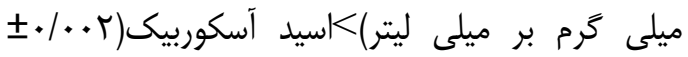

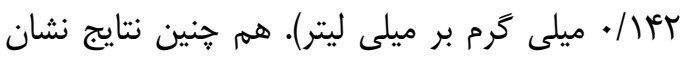

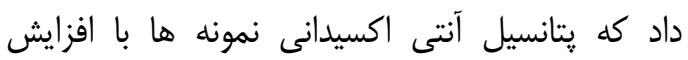
غلظت آن ها افزايش مى يابد(شكل شماره ()). آناليز بيوشيميايى بافت كليه: نتايج حاصل از آناليز آنايز بيوشيميايى بافت كليه مشخص نمود كه فعاليت آنزيم

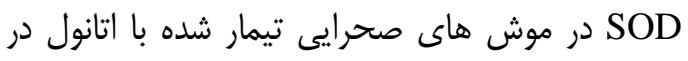

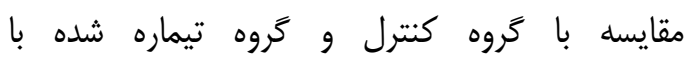
عصاره+|تانول، افزايش معنى دارى(P<0.05) نشان داد. ميزان فعاليت SOD به دنبــــال افزايـــش استرس

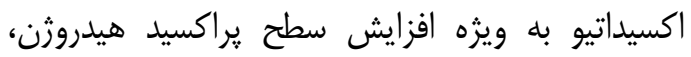

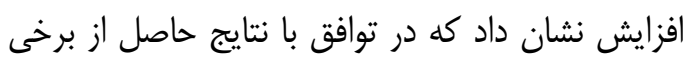

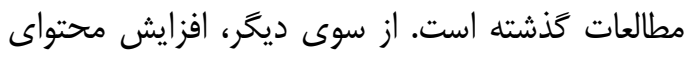
يروتئين كل و MDA در بافت كليه موش هاى صحرايى تيمار شده با اتانول، معنى دار(P<0.05) نبود

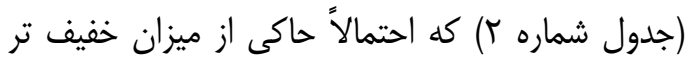

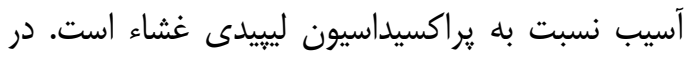
يزوهش حاضر به دليل فعاليت آنتى اكسيدانى بالاتر عصاره برى نسبت به ساقه، از عصاره برى جهت لئ تيمار موش هاى صحرايى استفاده شد. تيمار با اين عصاره

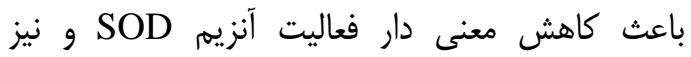
محتواى يراكسيد هيدروزن در مقايسه با موش هاى

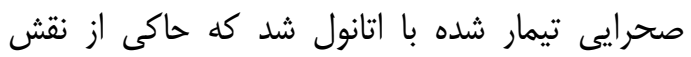
حفاظتى آن در كاهش استرس اكسيداتيو و نيز تعديل تخريب بافت كليه بود(جدول شماره ؟ان). مطالعات بافت شناسي: نتايج حاصل از مطالعات بافت شناسى كليه مشخص نمود كه بافت كليه در موش هاى صحرايى تيمار شده با اتانول، در مقايسه با باليه ساختار طبيعى بافت كليه در موش هاى صحرايى كروه

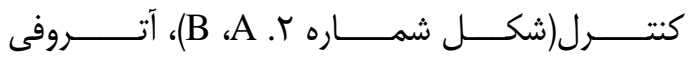

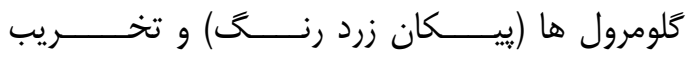

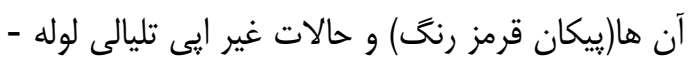

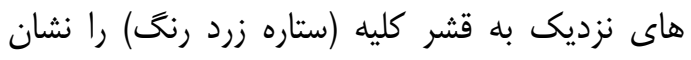

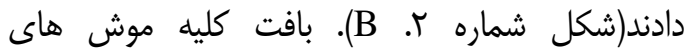
صحرايى تيمار شده با عصاره به همراه اتانول، كاهش

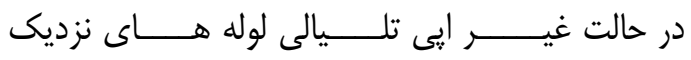

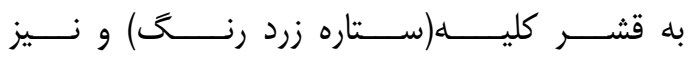

آن گاه بافت با درجات صعودى اتانول، آبخيرى و توسط

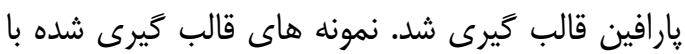

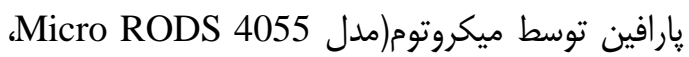

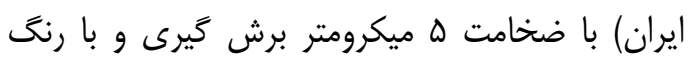

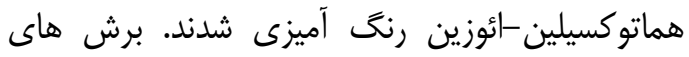

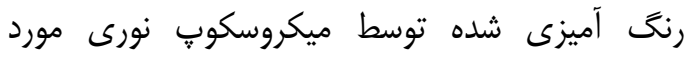

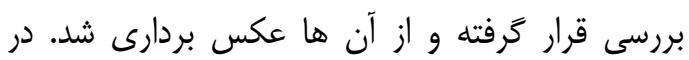

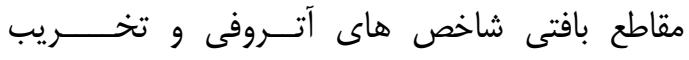

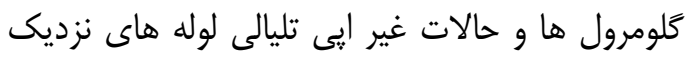

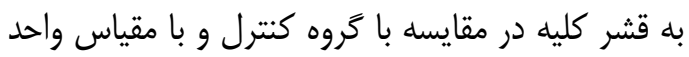
مورد بررسى قرار ترفت.

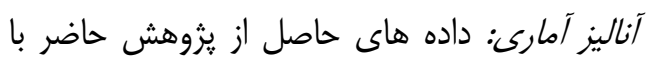

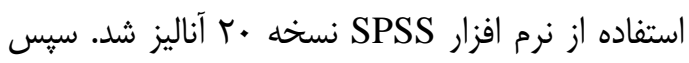

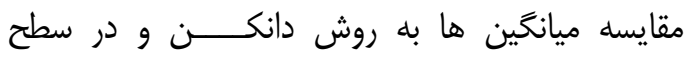

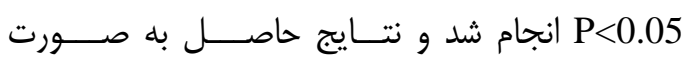
ميانخين 土 انحراف معيار بيان شد.

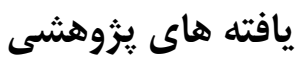
ارزيابى محتواى فنل و فلاونوئيد تام و فعاليت آنتى ئى

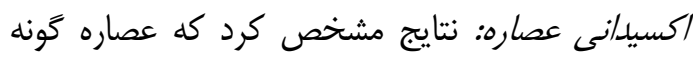

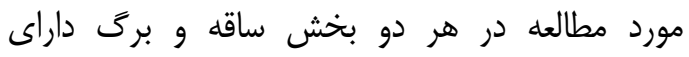

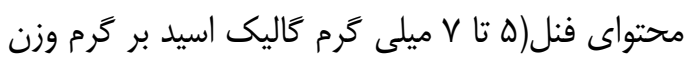

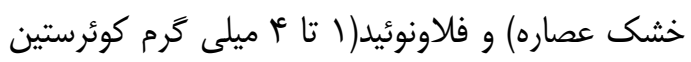

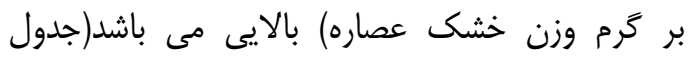

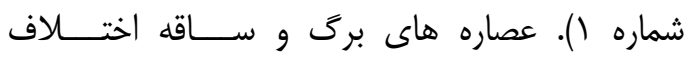
معنى دارى(P<0.05) در محتواى فنل تام نداشته، اما

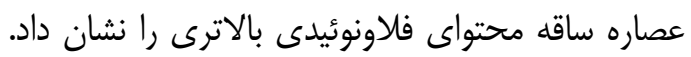

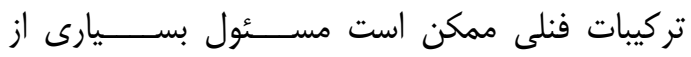

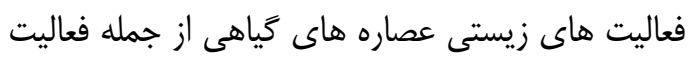

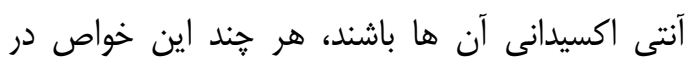

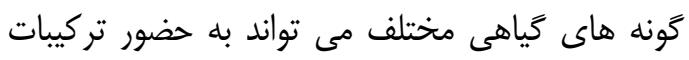

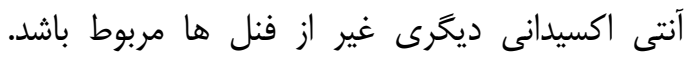

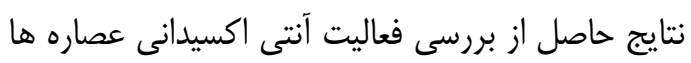

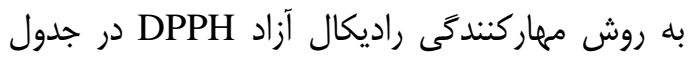

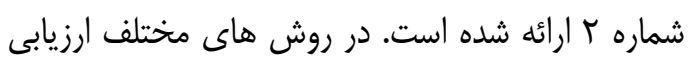

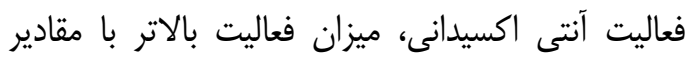

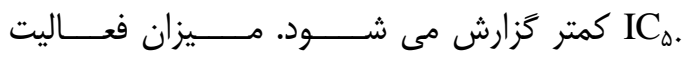

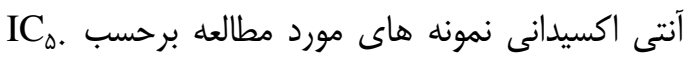

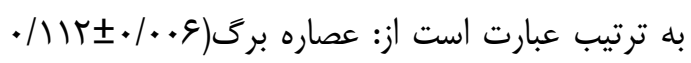




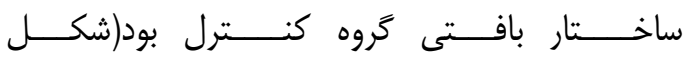

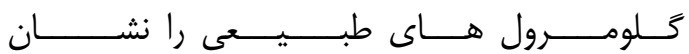

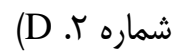

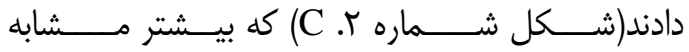

جدول شماره ا. محتواى فنل و فلاونوئيد تام و فعاليت آنتى اكسيدانى عصاره تَونه G. glabra

\begin{tabular}{|c|c|c|c|c|}
\hline فعاليت أنتىاكسيدانى IC50) value) & (ميلى كرم بر كرم وزن خلاونويك عصاره) & 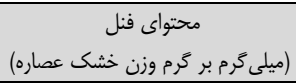 & & نمونه \\
\hline$b \cdot / . .9 \pm . / 11 r$ & $b \cdot / V \Psi \pm 1 / g 4$ & a) $/ \cdot r \pm s / \Lambda r^{c}$ & برك & \multirow[t]{2}{*}{ عصاره كياه شيرين بيان } \\
\hline b./.r土 & a. $/ 91 \pm r / \wedge q$ & a. $/ 9 \Delta \pm \Delta / r q$ & ساقه & \\
\hline$a \cdot / \cdot r \pm \cdot / N F$ & - & - & - & اسيد آسكوربيك \\
\hline
\end{tabular}

جدول شماره r. اثر عصاره برتى تونه G. glabra بر شاخص هاى بيوشيميايى بافت كليه در آسيب ناشى از اتانول

\begin{tabular}{|c|c|c|c|c|}
\hline \multicolumn{4}{|c|}{ شاخصهاى بيوشيميايى } & \multirow[b]{2}{*}{ 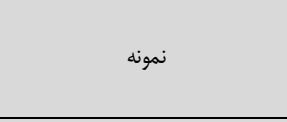 } \\
\hline 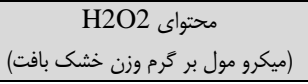 & 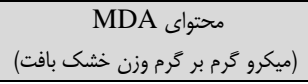 & $\begin{array}{l}\text { SOD فعاليت آنزيم) } \\
\text { (U/mg protien) }\end{array}$ & 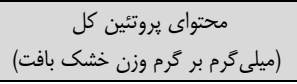 & \\
\hline$a \cdot / \cdot . r \pm \cdot / \cdot q 1$ & $a \cdot 1 \cdot .+ \pm \pm . / \cdot 19$ & a $/ / r \pm \Delta \backslash / q 1$ & $a \cdot / \cdot . \Delta \pm \cdot / . \Delta q$ & اتانول \\
\hline$b \cdot / . . q \pm \cdot / \cdot r)$ & $\mathrm{a} \cdot / . .1 \pm \cdot / \cdot 11$ & $b \cdot / q \pm r / / A r$ & $\mathrm{a} \cdot 1 \cdot \cdot v \pm \cdot / .94$ & اتانول+ عصاره برك كياه شيرينبيان \\
\hline $\mathrm{b} \cdot / \cdot 11 \pm \cdot / \cdot \mathrm{rA}$ & $a \cdot / \cdot \cdot \Delta \pm \cdot / \cdot 14$ & b $/ / \pm r \cdot / r r$ & $a \cdot 1 \cdot 1 \cdot \pm \cdot 1.91$ & عصاره برك كياه شيرينييان \\
\hline $\mathrm{b} \cdot / \cdot \cdot v \pm \cdot / \cdot r \Lambda$ & $a \cdot 1 . .9 \pm . / .1 r$ & b $\backslash / \bar{s} \pm \kappa \psi / \Delta \varepsilon$ & a./.rv $\pm \cdot \cdot \cdot \Delta s$ & كتنرل \\
\hline
\end{tabular}

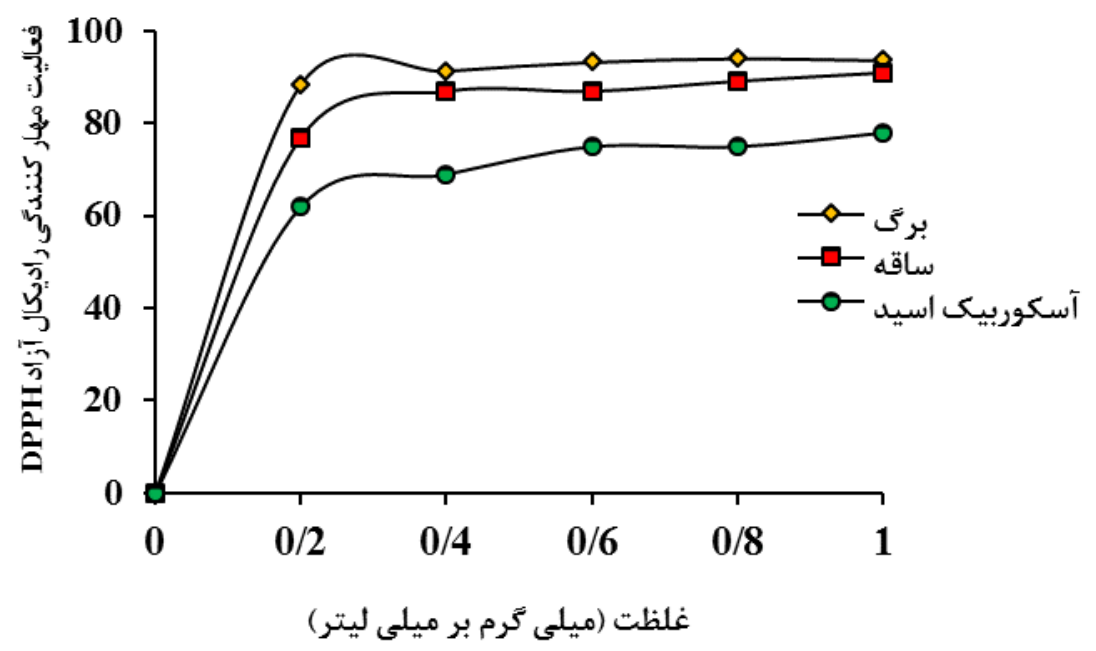

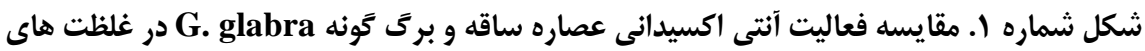

مختلف و اسيد آسكوربيك به عنوان استاندارد 


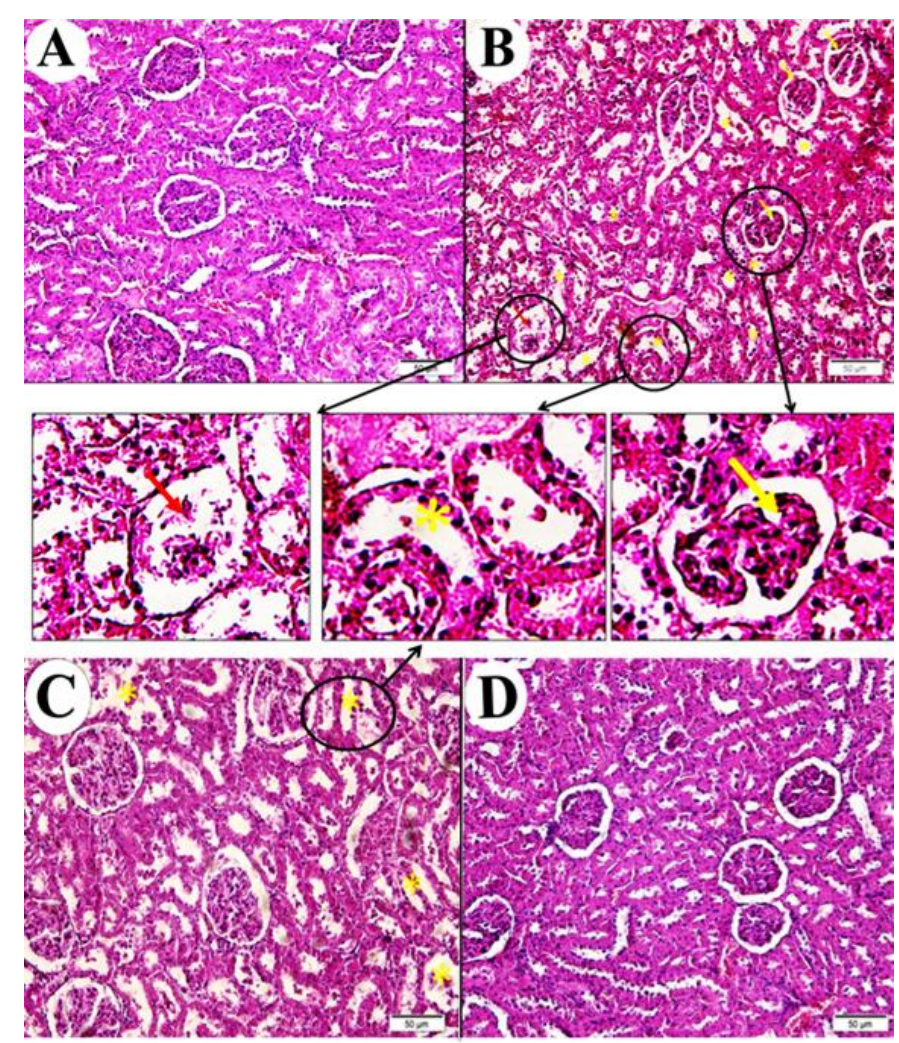

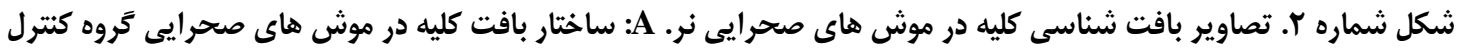

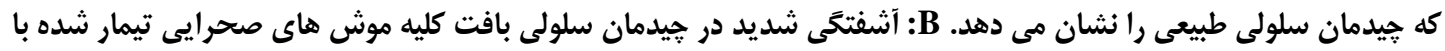

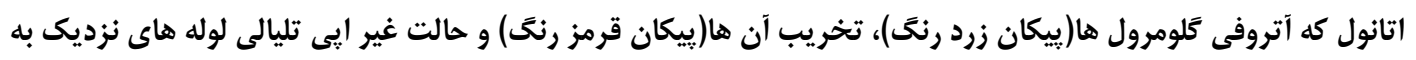

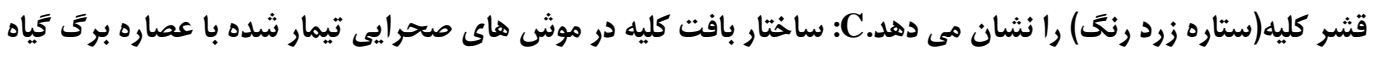

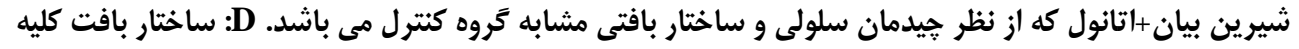

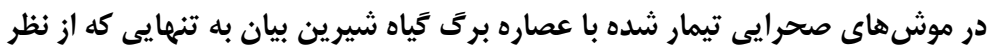

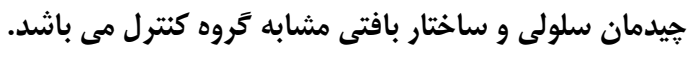

مى توانند با راديكال هاى آزاد اكسيثن و نيتروزن

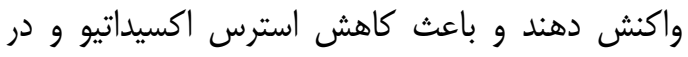

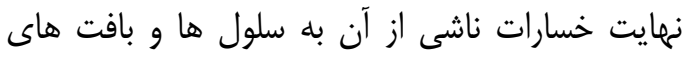

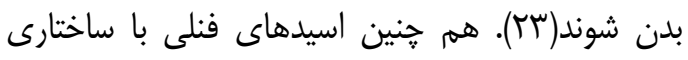

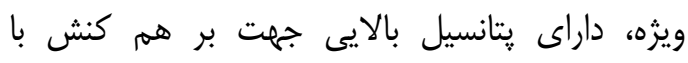

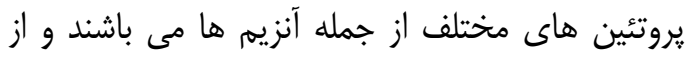

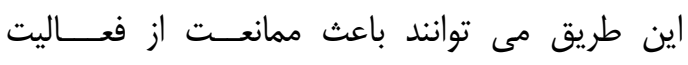
آنزيم هايى مانند ايزوفرم هاى مختلف سيتوكرم P450،

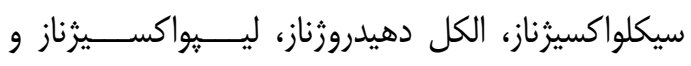

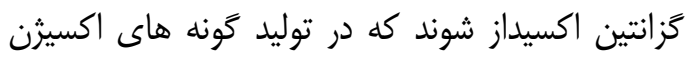

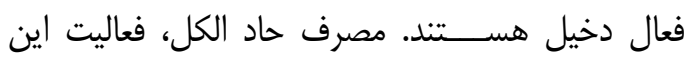

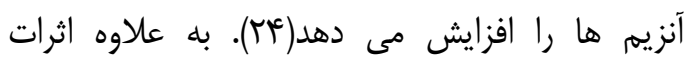
همكردار يا متضاد يلى فنل ها با عوامل آنتى اكسيدانى رهي

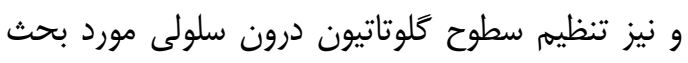

بحث و نتيجه كيرى نتايج يزوهش حاضر نشان دادي كيرى كه عصاره گياه دارويى شيرين بيان داراى سطوح بالايى از تركيبات فنلى است و در برابر مسموميت كليوى القاء شده با دان دارئ تركيات اتانول در موش هاى صحرايى نر نقش حفاظتى دارد.

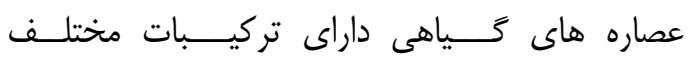
آنتى اكسيدانى از جمله يلى فنل ها هستند.

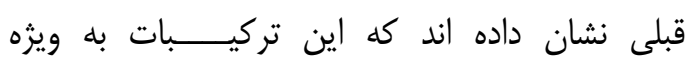

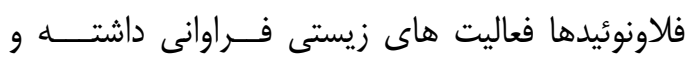

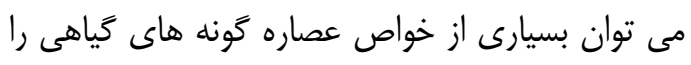

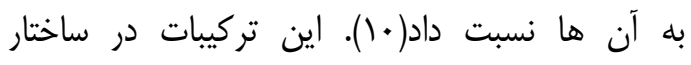

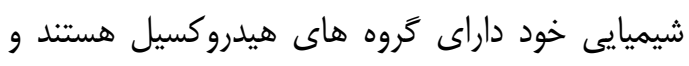

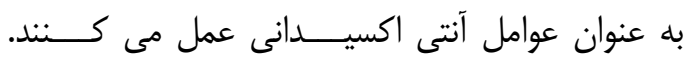

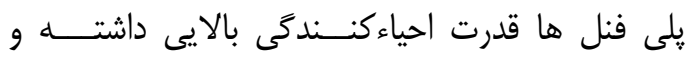


جمله ييام رسانى سلول دارد. توليد راديكال هاى آزاد ممكن است تحت تاثير مصرف الكل افزايش يابد كه در دران صورت عدم حضور مكمل هاى آنتى اكسيدانى، به سلول ها و بافت هاى بدن آسيب مى رساند. استالدئيد

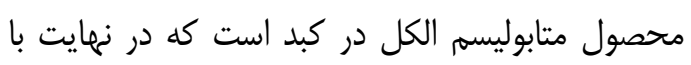

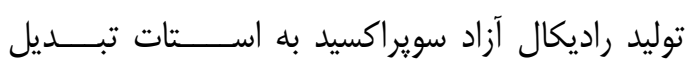
مى شود. كليه نيز تحت تاثير راديكال هاى آزاد حاصل

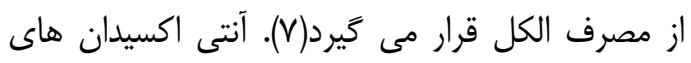

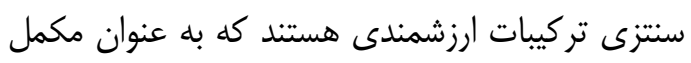
سيستم آنتى اكسيدانى سلول مى توانند در ييشخيرى و ورندي

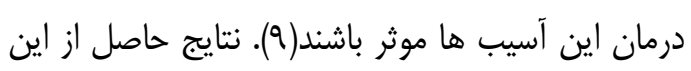

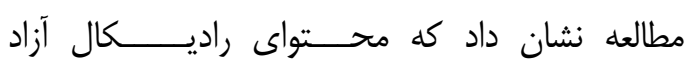

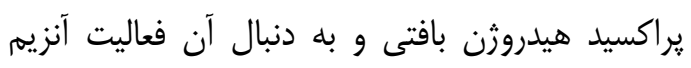
أنتى اكسيدانى SOD در موش هاى هرئى صحرايى تيمار

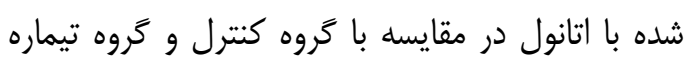

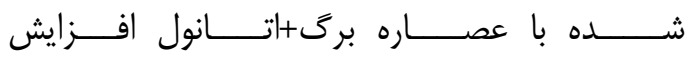

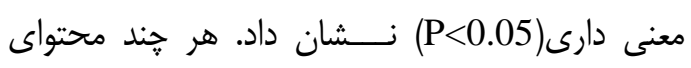

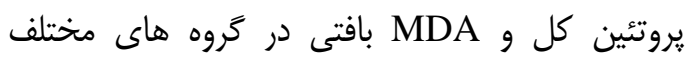
تفاوت معنى دارى نشان نداد. به نظر مى رسد اتانول در درو

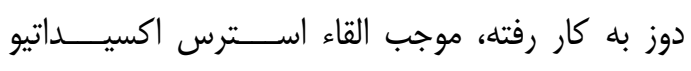

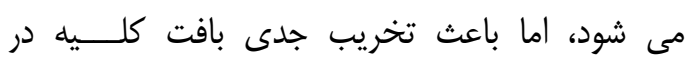

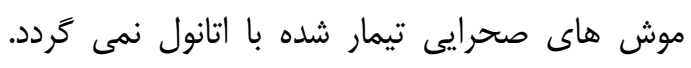

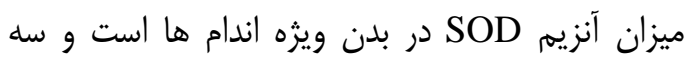

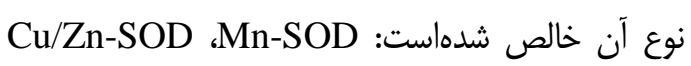

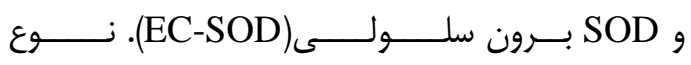
Cu/Zn-SOD

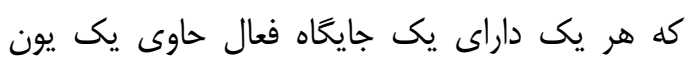

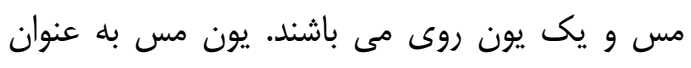

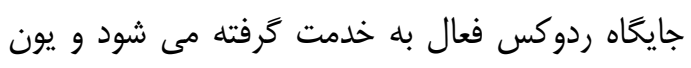

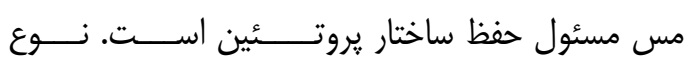

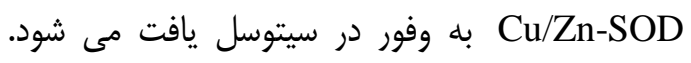
نوع Mn-SOD در ماتريكس ميتوكندريايى حضور دارد

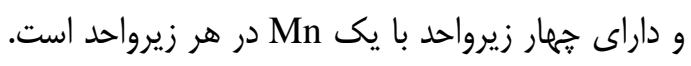
در مطالعه حاضر فعاليت SOD در كليه موش هاى دراى صحرايى تحت تيمار اتانول افزايش يافت كه احتمالاً

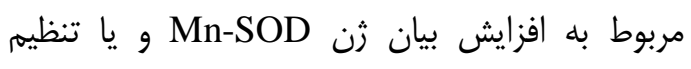
افزايشى فعاليت Cu/Zn-SOD در كليه مى باشد. بيش بيش

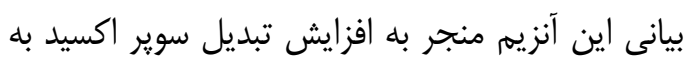

قرار گرفته است(مه). نتايج حاصل از يزوهش حاضر

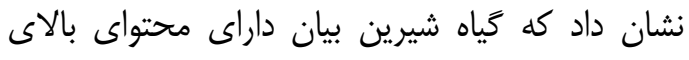

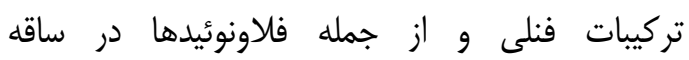

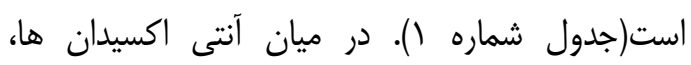

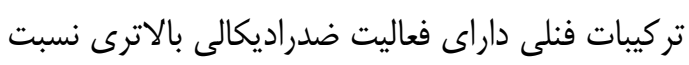

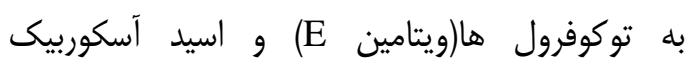
(ويتامين C) هستند(T) (T). نتايج حاصل از ارزيابى فعاليت آنتى اكسيدانى در يزوهش حاضر نشان داد كه عصاره برى گونه مورد مطالعه واجد فعاليت آنتى اكسيدانى

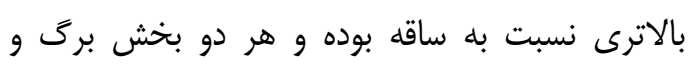

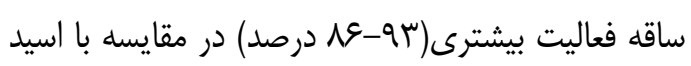

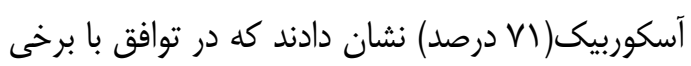

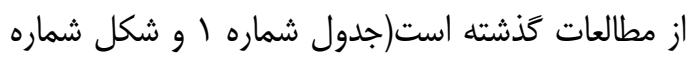

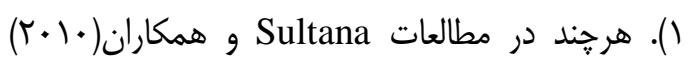
ميزان فعاليت آنتى اكسيدانى عصاره ريشه كـياه

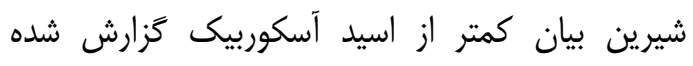

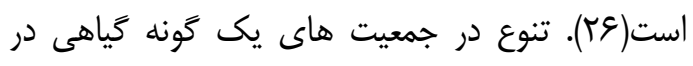

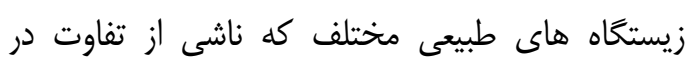

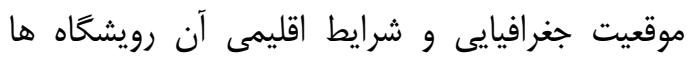
است، مى تواند در محتواى كمى و كيفى متابوليت هاى

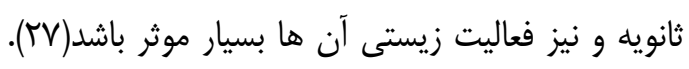

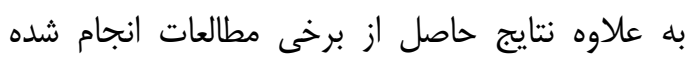

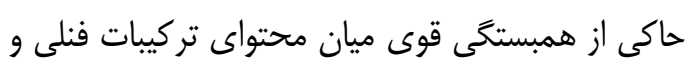

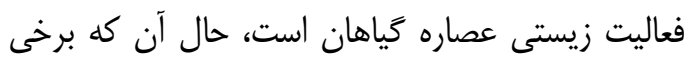

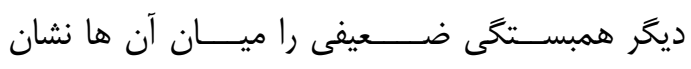

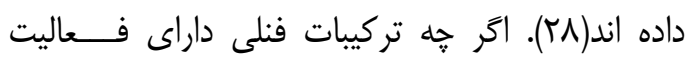

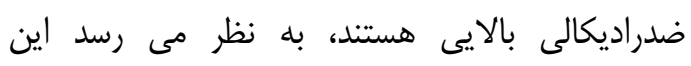

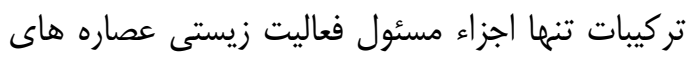

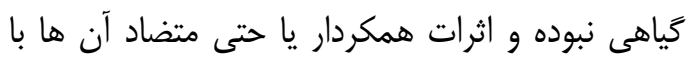

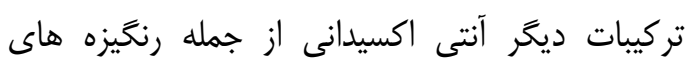

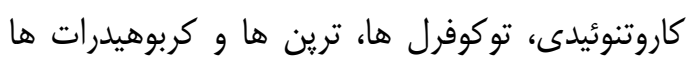
در مجموع تعيين كننده ميزان فعاليت زيستى عصاره ها

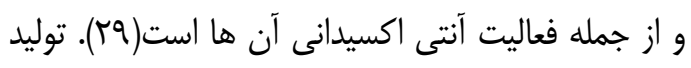

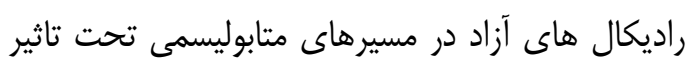

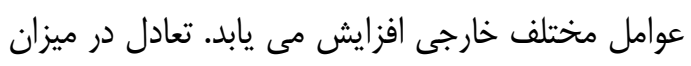

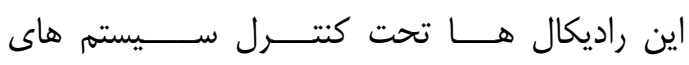
آنتى اكسيدانى سلول مانند كاتالاز و و سويراكسيد ديسموتاز، نقش مهمى در تنظيم فرآيندهاى سلولى از سلاز 
مشابهى به دست آمد و بافت كليه موش هاى صحرايى تيمار شده با اتانول در مقايسه با گروه كنترل، آتروفى و تخريب كلومرول ها و حالت غير ايى تليالى لوله هاى نزديك به قشر كليه را نشان داد. در بافت كليه تيمار شده با عصاره برگ به همراه اتانول، كاهش حالت غير ايى تليالى لوله هاى نزديك به قشر كليه و نيز وجود كلومرول هاى طبيعى مشاهده شد كه با ساختار بافت كليه گروه كنترل مشابه بود. تا كنون مطالعه ایى در

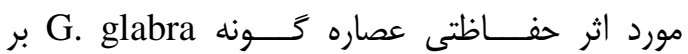
شاخص هاى بيوشيميايى و بافت شناختى در آسيب كليوى القاء شده با اتانول انجام نشده است. نتايج حاصل از مطالعات بافت شناسى كليه، نتايج مطالعات بيوشيميايى را تائيد نمود. در مجموع نتايج يثوهش حاضر نشان داد كه عصاره گونه G. glabra داراى سطوح بالايى از تركيبات فنلى است و يتانسيل حفاظتى خوبى در برابر مسموميت كليوى القاء شده با اتانول دارد و مى تواند در آينده به عنوان منبعى اميدبخش دريك مريك راستاى توليد دارو جهت جلوگيرى يا درمان اغلب بيمارى هاى حاصل از استرس اكسيداتيو و به ويزه مسموميت هاى كليوى مورد توجه قرار گيرد. سباسَّزارى

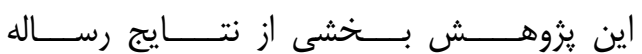

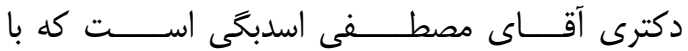

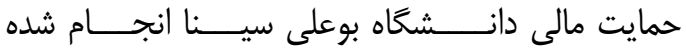

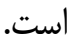

\section{References}

1. Aruoma OI, Cuppette SL. Antioxidant methodology invivo and in vitro concept. Champaign IL AOCS Puplication. 1997; P.142-69.

2. Valko M, Leibfritz D, Moncol J. Free radicals and antioxidants in normal physiological functions and human disease. Int J Biochem Cell Biol 2007; 39: 44-84. doi:10.1016/j.biocel.2006.07.001.

3. World Health Organization. Global status report on alcohol and health. WHO Geneva. 2014.

4. Poschl G, Seitz HK. Alcohol and cancer. Alcohol 2004; 39: 155-65.
يراكسيد هيدروثن مى گردد. انباشتخى يراكسيد هيدروزن در كليه به دنبال تيمار اتانول در مطالعه حاضر، ممكن است ناشى از القاء استرس اكسيداتيو و توسعه آسيب كليوى حاصل از الكل باشد. تيـــمار موش هاى صحرايى با عصاره گونه مورد مطالعه باعث كاهش برخى از شاخص هاى بيوشيميايى ناشى از استرس شد كه نقش حفاظتى عصاره را به عنوان يك مكمل آنتى اكسيدانى در كاهش استرس اكسيداتيو ناشى از اتانول و تخريب بافت كليه نشان داد. هر تجند شاخص هاى بيوشيميايى ارزيابى شده و ساختار بافتى كليه در موش هاى صحرايى تيمار شده با عصاره برگ به تنهايى(گروه ع) با گروه كنترل اختلاف معنى دارى نداشت. نتايج مطالعات قبلى نيز نشان داده است كهو مصرف حاد اتانول باعث القاء ڤيراكسيداسيون ليييد و تخريب شديد بافت ها و نيز كاهش فعاليت آنزيم هاى آنتى اكسيدانى از جمله سوير اكسيد ديسموتاز در كليه

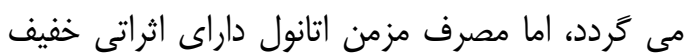
در غشاء و تغيير برخى از شاخص هاى بيوشيميايى و

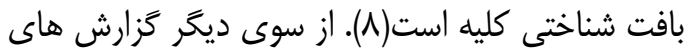
متعددى در مورد نقش حفاظتى تركيبات مختلف در

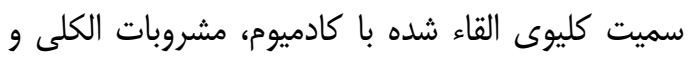
جنتامايسين وجود دارد(·ץ). مطالعات قبلى نشـــــان داده اند كه اتانول باعث افزايش آتروفى و تخريب كلومرول ها و حالت غير ايى تليالى لوله هاى نزديك به

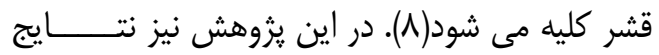

5. Clemens DL, Jerrells TR. Ethanol consumption potentiates viral pancreatitis and may inhibit pancreas regeneration preliminary findings. Alcohol 2004; 33: 183-9.

doi.org/10.1016/j.alcohol.2004.07.001.

6. Lieber CS. Biochemical and molecular basis of alcohol induced injury to liver and others tissues. N Engl J Med 1988; 319: 1639-50.

doi:

10.1056/NEJM198812223192505.

7. Pacht ER, Davis WB. Role of transferin and ceruloplasmin in antioxidant activity of lung epithelial lining fluid. J Appl Physiol 
1988; 64: 2092-9. doi.org/10.1016/j.taap. 2006.05.013.

8. Puddey IB, Burke V, Croft K, Beilin LJ. Increased blood pressure and changes in membrane lipids associated with chronic ethanol treatment of rats. Clin Exp Pharmacol Physiol 1995; 22: 655-7. doi.org/10.1111/j.1440-

1681.1995.tb02083.x.

9. Zhang HY, Yang DP, Tang GY. Multipotent antioxidants from screening to design. Drug Discover Today 2006; 11: 749-54.

doi.org/10.1016/j.drudis.2006.06.007.

10. Yu L, Perret J, Davy B, Wilson J,

Melby CL. Antioxidant properties of cereal products. J Food Chem Sci 2002; 67: 2600-

3. doi.org/10.1111/j.1365-

2621.2002.tb08784.x.

11. Bown D. The royal horticultural society encyclopedia of herbs and their uses. Dorling Kindersley Ltd London Publication.1995; P. 424-8.

12. Farag MA, Porzel A,Wessjohann LA. Unequivocal glycyrrhizin isomer determination and comparative in vitro bioactivities of root extracts in four Glycyrrhiza species. J Adv Res 2015; 6: 99104. doi.org/10.1016/j.jare.2014.05.001.

13. Zheng LZ, Young WK, Yu PY, Jie Z. Glycyrrhiza radix methanol extract attenuates amphetamine-induced locomotor sensitization and conditioned place preference. Evid Based Compl Alt 2014; 2 : 1-7. doi.org/10.1155/2014/152063.

14. Soxhlet, F. Diegewichts analytische bestimmung des milchfettes. Din Polytech J 1879; 232: 461.

15. Wolfe K, Wu X, Liu RH. Antioxidant activity of apple peels. J Agric Food Chem 2003; 51: 609-14. doi:10.1021/jf020782a.

16. Luximon A, Bahorun T, Soobrattee MA, Aruoma OI. Antioxidant activities of phenolic, proanthocyanidin, and flavonoid components in extracts of Cassia fistula. J Agric Food Chem 2002; 50: 5042-7. doi: 10.1021/jf0201172.

17. Donald SMC, Prenzler PD, Autolovich M, Robards K. Phenolic content and antioxidant activity of olive extracts. Food Chem 2001; 73: 73-84. doi.org/10.1016/S0308-8146(00)00288-0.

18. Jayanthi MK, Subbarao V, Madhunapantula D, Reddy K, Mryuthunjaya K, Manjula SN. Evaluation of anti-tumor activity of ethanolic extract of Glycyrrhiza glabra against Ehrlich ascites carcinoma in swiss albino Mice. Int $\mathrm{J}$ Basic Clin Pharmacol 2016; 5: 2153-8. doi: 10.18203/2319-2003.ijbcp20163253.

19. Alkhedaide A, Alshehri ZS, Sabry A, Abdelghaffar T, Soliman MM, Attia H. Protective effect of grape seed extract against cadmium-induced testicular dysfunction. Mol Med Rep 2016; 13: 31019. doi: $10.3892 / \mathrm{mmr} .2016 .4928$.

20. Bradford MM. A rapid and sensitive method for the quantitation of microgram quantities of protein utilizing the principle of protein-dye binding. Anal Biochem 1976; 72: 248-54. doi.org/10.1016/00032697(76)90527-3.

21. Beauchamp C, Fridovich I. Superoxide dismutase improved assay and an assay applicable to acrylamide gels. Annals Biochem 1971; 44: 276-87. doi.org/10.1016/0003-2697(71)90370-8.

22. Baryla A, Laborde C, Montillet JL, Triantaphylides C, Chagvardieff P. Evaluation of lipid peroxidation as a toxicity bioassay for plants exposed to copper. Environ Pollut 2000; 109: 131-5. doi.org/10.1016/S0269-7491(99)00232-8.

23. Karamian R, Asadbegy M. Antioxidant activity, total phenolic and flavonoid contents of three Onobrychis species from Iran. Pharm Sci 2016; 22: 112-9. doi: 10.15171/PS.2016.18.

24. Valentao P, Fernandes E, Carvalho F, Andrade PB, Seabra RM, Bastos ML. Hydroxyl radical and hypochlorous acid scavenging activity of small centaury Centaurium erythraea infusion. Phytomedicine 2003; 10: 517-22. doi:10.1078/094471103322331485.

25. Karami Z, Mirzaei H, Emamdjomeh Z, Sadeghimahoonak AR, Khomeiri M. Effect of harvest time on antioxidant activity of Glycyrrhiza glabra root extract and evaluation of its antibacterial activity. Int Food Res J 2013; 20: 2951-7.

26. Sultana S, Haque A, Hamid K, Urmi KF, Roy S. Antimicrobial, cytotoxic and antioxidant activity of methanolic extract of Glycyrrhiza glabra L. Agric Biol J North America 2010; 1: 957-60. doi:10.5251/abjna.2010.1.5.957.960.

27. Tosun M, Ercislis S, Sengul M, Ozer H, Polat T, Ozturk E. Antioxidant properties and total phenolic content of eight Salvia 
species from Turkey. Biol Res 2009; 42:

175-81. doi:/S0716-97602009000200005.

28. Siddique NA, Mujeeb M, Najmi AK, Akram K. Evaluation of antioxidant activity quantitative estimation of phenols and flavonoids in different parts of Aegle marelos. Int J Plant Physiol Biochem 2010; 4: 1-5. doi.org/10.1016/j.jscs.2010.10.005. 29. Conforti S, Sosa M, Marrelli F, Menichini GA, Statti D, Uzunov A, Tubaro $\mathrm{F}$, et al. In vivo anti-inflammatory and invitro antioxidant activities of Mediterranean dietary plants. J Ethnopharmacol 2008; 116: 144-51. doi.org/10.1016/j.jep.2007.11.015. 30. Atessahin A, Karahan I, Yilmaz S, Ceribasi AO, Princci I. The effect of manganese chloride on gentamicin induced nephrotoxicity in rats. Pharmacol Res 2003; 48: $\quad 637-42 . \quad$ doi.org/10.1016/S10436618(03)00227-5. 


\title{
Antioxidant Activity of Glycyrrhiza glabra L. Extract and Protective Effect of its Leaf Extract on Ethanol-Induced Nephrotoxicity in Male Rats
}

\author{
Karamian $R^{l^{*}}$, Asadbeigy $M^{l}$, Yari $S^{l}$
}

(Received: May 6, 2017

Accepted: July 8, 2017)

\begin{abstract}
Introduction: Acute alcohol consumption leads to induction of lipid peroxidation in renal tissues, but its chronic consumption has moderate effects on biochemical and histological characteristics of this organ. Antioxidants have protective effects against ethanol-induced oxidative stress and tissue injury. The aim of this study was to assess antioxidant activity of Glycyrrhiza glabra leaf and stem extracts and the protective effect of its leaf extract on ethanol-induced nephrotoxicity.
\end{abstract}

Materials \& methods: Total phenol and flavonoid contents of leaf and stem extracts of G. glabra were measured by Folin Ciocalteu and $\mathrm{AlCl}_{3}$ assays, respectively. Antioxidant activity of both extracts was assessed using 2, 2-diphenyl-1picrylhydrazyl (DPPH) free radical scavenging. In addition, protective effect of the leaf extract was assessed using biochemical and histological analyses of renal tissues of male Wistar rats, which were divided into four groups including group 1 or control (received $1 \mathrm{ml}$ distilled water daily), group 2 or ethanol group (received $1 \mathrm{ml}$ of $50 \%$ ethanol daily), group 3 or ethanol + leaf extract group (received 1 $\mathrm{ml}$ of $50 \%$ ethanol $+500 \mathrm{mg} / \mathrm{kg}$ leaf extract daily), and group 4 (received $500 \mathrm{mg} / \mathrm{kg}$ of leaf extract daily). All treatments are performed through intragastric administration. Biochemical and histological analyses were used for the evaluation of nephrotoxicity. For histological study, the samples were stained with Hematoxylin-Eosin and examined by light microscopy. Finally, all the data were analyzed by SPSS (Ver. 20) and grouped by Duncan's Multiple Range Test at $\mathrm{P}<0.05$ level.

Findings: There was no significant difference between total phenol contents of the stem and leaf extracts. However, the stem extract showed a higher total flavonoid content than the leaf extract. Also, both the extracts showed higher antioxidant activities (86-93\%) than that of ascorbic acid (71\%). Results from biochemical analysis indicated a significant increase in superoxide dismutase (SOD) activity and $\mathrm{H}_{2} \mathrm{O}_{2}$ content in the renal tissues of ethanol-treated rats in comparison with other groups; however, there were no significant changes in total protein and malondialdehyde (MDA) contents. Results from histological examination showed that alcohol consumption intensity injured kidney tissues, which was effectively moderated by the studied extract.

Discussion \& Conclusions: Results from the present study showed that G. glabra extract has biological activity and can be used in future as a new natural antioxidant in food and drug industries.

Keywords: Glycyrrhiza glabra L., Antioxidant activity, Ethanol, Nephrotoxicity, Phenol, Rats 